19 Revue d'histoire du XIXe siècle

Société d'histoire de la révolution de 1848 et des

révolutions du XIXe siècle

$2 \mid 1986$

Varia

\title{
George Sand-Marc Dufraisse. Correspondance inédite (28 mai-16 août 1848)
}

\section{Georges Lubin}

\section{OpenEdition \\ Journals}

Electronic version

URL: http://journals.openedition.org/rh19/11

DOI: 10.4000/rh19.11

ISSN: 1777-5329

Publisher

La Société de 1848

\section{Printed version}

Date of publication: 1 June 1986

ISSN: 1265-1354

Electronic reference

Georges Lubin, "George Sand-Marc Dufraisse. Correspondance inédite (28 mai-16 août 1848) », Revue d'histoire du XIXe siècle [Online], 2 I 1986, Online since 09 September 2008, connection on 01 May 2019. URL : http://journals.openedition.org/rh19/11 ; DOI : 10.4000/rh19.11

This text was automatically generated on 1 May 2019.

Tous droits réservés 
George Sand-Marc Dufraisse.

Correspondance inédite (28 mai-16 août 1848)

Georges Lubin

\section{ABSTRACTS}

No abstract available by now

Pas de résumé disponible actuellement

INDEX

Mots-clés: Correspondance, Littérature, Sand George, Dufraisse Marc 